\title{
The Effects of Worker's Behavior Changes on Batik Equipment in Traditional Batik Process of Oey Soe Tjoen
}

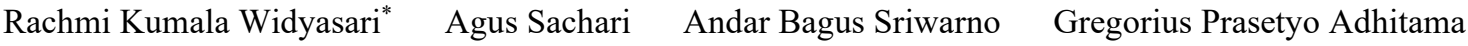 \\ Faculty of Fine Art and Design, Bandung Institute of Technology \\ Jl. Ganesha No. 10 Bandung, West Java, Indonesia 40132
}

\begin{abstract}
Batik Tulis is one of the world's worth preserving intangible heritage objects from Indonesia. Preservation of the batik industry also includes the conservation of the manufacturing process. Oey Soe Tjoen Peranakan Batik is one of the batik workshops that still maintains the traditional batik tulis process for almost a hundred years. This batik workshop located in the Kedungwuni area, Central Java, is now managed by Widianti Widjaja as the third generation. The intergenerational period causes differences in behavior in everyday life, including the process of making batik tulis. In the second and third generations, postural limitations founded, which also affected the equipment used in the process of making batik. The inconvenience factor in the process of making traditional batik tulis is one of the reasons that trigger changes in the equipment used. The purpose of this study is to examine changes in equipment used in the process of making traditional batik tulis in the Oey Soe Tjoen workshop. Through in-depth interviews, observations, and documentation in a certain period, it can be concluded that the influence of habits and comfort factors at work increased the work platform on some equipment used in making traditional batik tulis, especially at this workshop.
\end{abstract}

Keywords: Batik tulis, batik tools, behavior, postural, working platform

DOI: $10.7176 / \mathrm{ADS} / 80-01$

Publication date: January $31^{\text {st }} 2020$

\section{Introduction}

Batik is a collective work of art that involves many skilled workers who use dye technic and barriers to fabric using hot wax (Kudiya, 2019). One type of batik is the batik Nyonya or batik pesisir. The characteristic of batik pesisir is famous for its cheerful colors typical of Chinese people and more flexible to combine European and Chinese decorative styles (Komunitas Lintas Budaya Indonesia dan Intisari, 2018). One of the batiks that are famous for foreign countries, especially among Chinese Peranakan women in Singapore and Malaysia, is Oey Soe Tjoen Peranakan batik.

Oey Soe Tjoen Batik is one of the batik pesisir originating from the Kedungwuni sub-district, $10 \mathrm{~km}$ south of Pekalongan city, Central Java. Oey Soe Tjoen founded this batik workshop in 1925 as a descendant of Peranakan batik from the Oey family, who had produced batik from generation to generation (Liong, 2014). Batik Oey Soe Tjoen is famous for floral bouquets pattern inspired by Dutch, intricate details, and coloring techniques that produce three-dimensional effects, typical of Kedungwuni Peranakans batik. Widianti Widjaja, as the third generation of the Oey Soe Tjoen batik, still maintains hereditary the tradition of making batik tulis. This batik business threatened will be stopped in the next ten years because of the time-consuming process, with a high level of accuracy and decreasing human resources.

The making of Oey Soe Tjoen batik was divided into several stages, starting from the preparation stage to the delivery stage (Liong, 2014). The preparation stage starts from making a pattern on paper, which is then redrawn on fabric using canting as a pen and hot wax as ink. Canting is a tool made of wood as a handle and copper as a nib and container for the wax (Dharsono, 2019). The canting process is carried out on both sides of the fabric and takes place in the canting workstation. After the canting process, the fabric is cleaned with water on the washing table. The next process is coloring using a dye technique. The level of complexity is not only based on the pattern and details, but also from the color. After being dyed, the fabric is soaked in hot water to remove the wax, this process is known as Lorod. After completion, the fabric can be dried in the sun. The canting process, the coloring process with the dyeing technique, and the lorod process took place repeatedly following the design of the pattern.

The equipment that uses in the process of making Oey Soe Tjoen batik, at a glance, is almost the same as other batik houses. They are canting, gawangan, which is a tool to attach fabric during the canting process, a stove to heat the wax, a stool, a dyeing tub for the coloring process, a barrel and a furnace to dissolve the wax on the fabric in lorod process. However, some equipment looks different. In the correcting process, before fabric entering the washing process, there is a table the size of fabric - similarly, in the washing process, larger table as a container for washing fabric before entering the dyeing process.

The dyeing process uses two types of dye tools. A first tool is a traditional tool that has been used for generations in the dyeing process since the first generation of Oey Soe Tjoen, whereas the second tool is a new dye modification tool used since the third generation of Oey Soe Tjoen. This new modification dyeing tool is 
specially designed due to complaints from workers, including Widianti herself, as the business owner. The consideration for using this modification dyeing tool is the emergence of worker's complaints of lower back pain when dyeing a large amount of fabric. Another consideration is the lack of workers who can do this process so that sometimes the dyeing process is delayed. This postural inconvenience also becomes a consideration for making modifications to the correction table and washing table equipment.

Knowledge of postural in traditional and cultural-based work is indeed not easy to find. However, ergonomically repetitive activity with bending posture causes tension in the spinal muscles and pressure on the abdominal muscles. If this activity held for a long time can cause pain in the back.
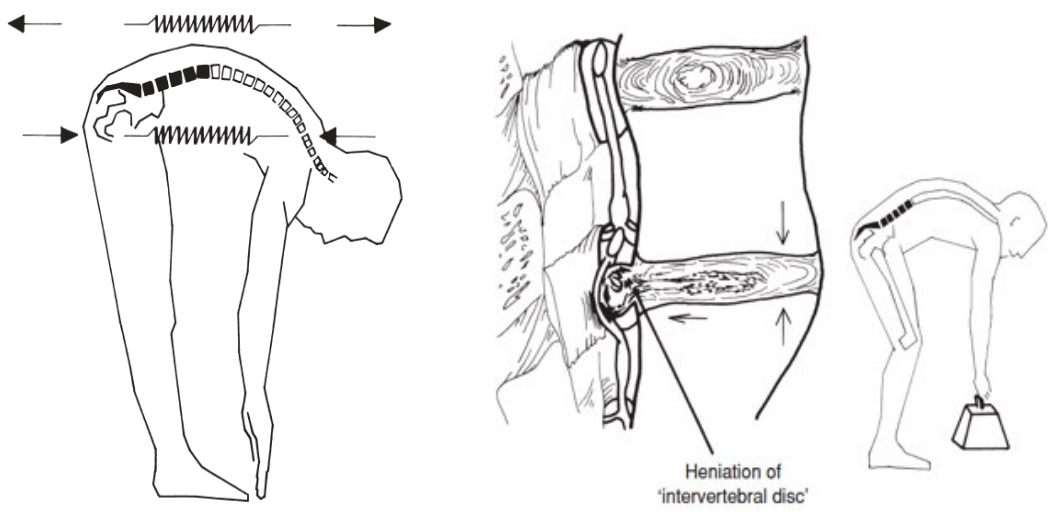

Figure 1. The illustration of worker activities with bending and lifting weights

Source: Bridger, 1995

The correction, washing, and coloring process using traditional dyes tool with a low working platform, can cause inconvenience for workers. The situation is supported by monotonous movements over a long period and also carrying the load so it can cause muscular fatigue at a certain point on the body of the worker (Kroemer \& Grandjean, 2009). This because of an uneven burden on one point of the body.

Initially, traditional work might not have considered ergonomics and comfort factors. Nevertheless, along with the development of science and technology, awareness of the comfort of the body at work raises critical considerations that bring changes in tools and workspaces. Therefore, some changes were made in the equipment used, based on several considerations which will be explained in the results section. The following is a table of work platform height relationships for standing work based on gender and type of work:

\begin{tabular}{lcc}
$\begin{array}{l}\text { RECOMMENDED WORK SURFACE HEIGHTS FOR STANDING WORKERS } \\
\text { (in centimeters)" }\end{array}$ \\
\hline Task requirement & Male & Female \\
\hline Precision work & $109-119$ & $103-113$ \\
Light assembly work & $99-109$ & $87-98$ \\
Heavy work & $85-101$ & $78-94$ \\
\hline "From Ayoub (1973). & &
\end{tabular}

Figure 2. Recommended work surface heights for working in a standing position Source: Bridger, 1995

\section{Methods}

This study uses a qualitative method with a behavioral approach through observation, documentation, and indepth interviews with the batik workers in the Oey Soe Tjoen workshop. The building has three different functions at once, namely as a residence, a grocery store, and a batik workshop. The batik workshop is on the backside of the building.

Interviews were conducted with the correction, washing, and dyeing workers, namely Widianti, along with several assistants who had worked with her for approximately twenty years since the second generation Oey Soe Tjoen. Widianti directly took a role in the process of correction and dyeing because the correction process is also a quality control process. Meanwhile, in the coloring process, the mixing of dye ingredients is a hereditary inheritance only for descendants of the Oey family.

The data collection process takes several months. In the initial stage of data retrieval, the coloring process worker uses two units of modification tools and one unit of traditional tools. The changes have an impact on the use of tools, so brings changes to the layout in the workstation. The initial stage of data collecting begins with an informal interview with Widianti as the owner and worker in the Oey Soe Tjoen batik house. The data generated in the form of the background and history of the founding of this batik workshop. Also, documentation of the traditional motifs and patterns typical of batik Oey Soe Tjoen, mostly in the form of flower bouquet motifs and documentation of spaces used in the process of making batik. Furthermore, data is in the form of measurements 
of equipment dimensions and space used in the batik process and the process of the making batik itself. It starts with making a pattern to the process of drying fabric. Data on the process of making batik is taken in several stages because of the long and complicated batik process and also the limited number of workers. The following collecting data is about the behavior of workers and how they interact with each other. That includes the interaction of workers with the space used in the batik process.

\section{Results and Discussion}

The Oey Soe Tjoen building has three different functions. The first function is the grocery retail function, located in the front area on the left side of the building. The second function is the private function located on the right side of the building. While the third function is the batik workshop located in the rear are of the building. Several spaces accommodate activities in different functions. For example, the living room, as a transition for guests to enter the private area but also as a working area for Widianti to make the batik design. The rear of the building, beside the batik workshop, also a private area for retail grocery workers.

The workshop is an ample space that accommodates batik activities following the sequence of the process. The first area encountered was the dyeing process area or dyeing workstation, which located in the front area of the Oey Soe Tjoen batik workshop, directly adjacent to the main house as a residence. The dyeing workstation has a dual function, like a laundry room. This workstation is directly adjacent to the Lorod workstation. The next is the washing area located in the middle of the workshop.

In contrast to dyeing, the washing tool is more permanent, and this is because the equipment is massive, so less possibility to make change the layout of the area. The rear area in the workshop is the canting and correction process or canting workstation, which carried out just before the washing process takes place. Therefore, the correction table is also a moveable tool.

The batik process at the Oey Soe Tjoen workshop takes place from the rear to the front area, which is directly adjacent to the private function, as seen from the layout as follows:

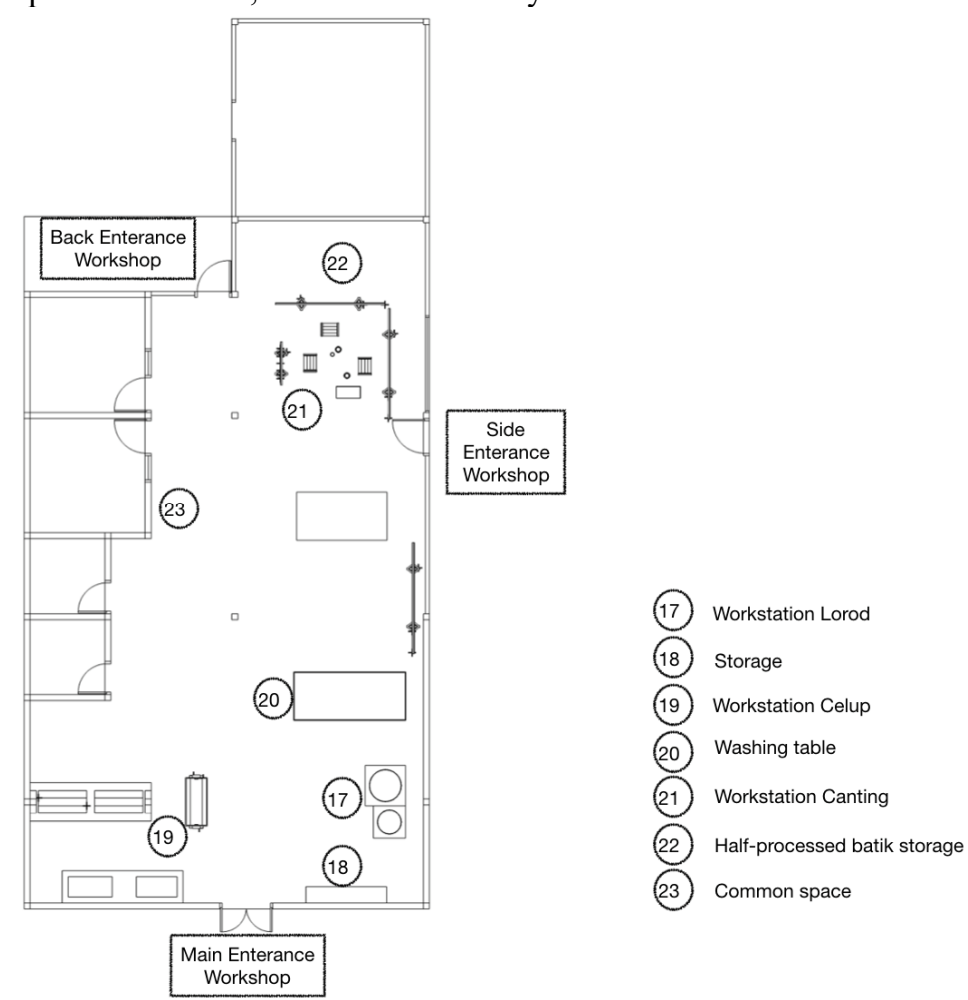

Figure 3. The layout of Oey Soe Tjoen Batik workshop

Following are the results and discussion of equipment that has changed in the work platform in the batik process, namely the correction process, the washing process, and the dyeing process:

\subsection{The Correction Process}

Nowadays, Widianti using the correction table for the correction process. The correction table is made from plywood boards with dimensions that are more or less following the size of batik fabric that stretched without folds. Widianti first used the correction table as the third generation of Oey Soe Tjoen batik in correcting canting's results before entering the washing process. The use of the table is because Widianti's habits do everything, especially for detailed work, on the table. Initially, the process of canting and correcting used a 
gawangan but now is using a table. With the unfolded fabric and the increase in the work platform, Widianti felt that she could do this process better.

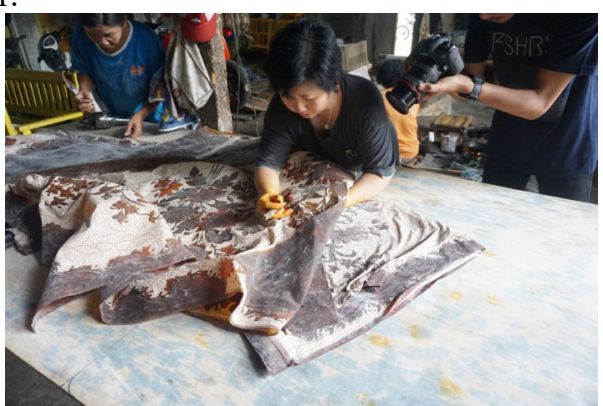

Figure 4. Widianti Widjaja is doing the batik correction process using a correction table

The correction process does not take place every day. Therefore, the equipment can also be stored and used when needed. The correction process, which is part of the canting process, makes the correction table usually placed close to the canting workstation. The canting process uses moveable gawangan, which can adjust to the number and position of the batik workers involved in it. The combination between the gawangan and the correction table is a sign that there is friction in working procedures due to differences in the batik worker's habits of doing their work.
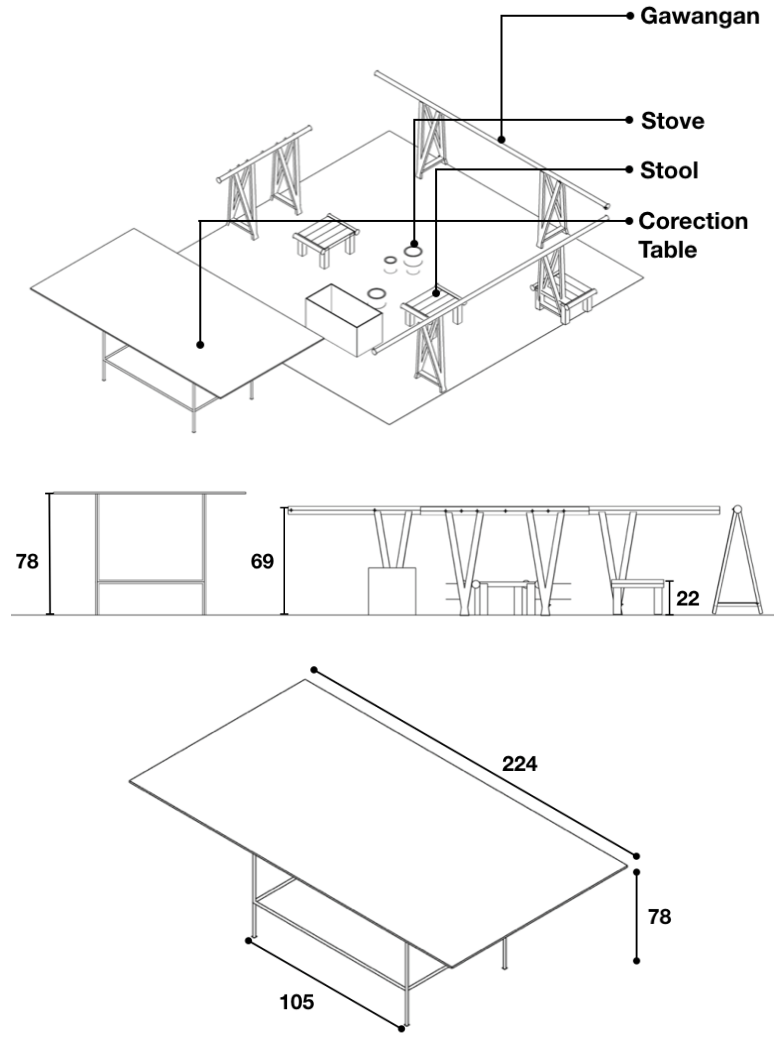

Figure 5. The layout of canting workstation and the dimension of correction table in centimeter

\subsection{The Washing Process}

Washing tables have been around since the second generation of Oey Soe Tjoen. The washing process initially took place at the same level as of the workshop floor, then changed to using a table made of wood as the base. The main reason for this changing tool is because of Muljadi Widjaja's posture as the second generation Oey Soe Tjoen is not possible to sit squatting in the process of washing. The washing process on the table continues until now. The process of washing fabric usually requires two workers, so that the flour attached to the fabric is completely clean. Therefore, workers use a soft brush to clean from two different directions and work together to turn the fabric to clean the other side. 


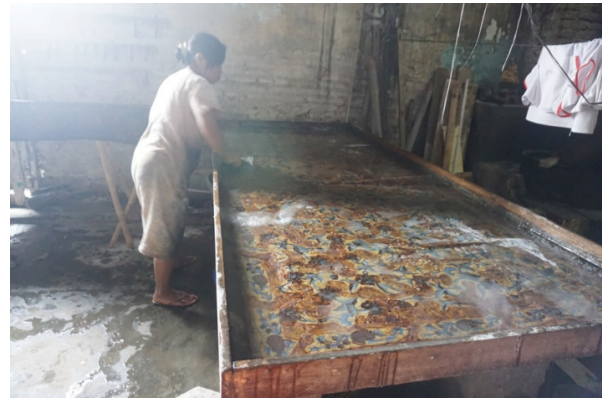

Figure 6. A worker in washing process using washing table

In contrast to the correction table, although the washing process does not take place every day, the washing table is non-moveable. The material for the washing table is of brick and cement as a massive cantilever structure and table mat made of moveable wood boards so that it can be releasable from the structure. The drain completes the wooden table mat for the remaining washing water.

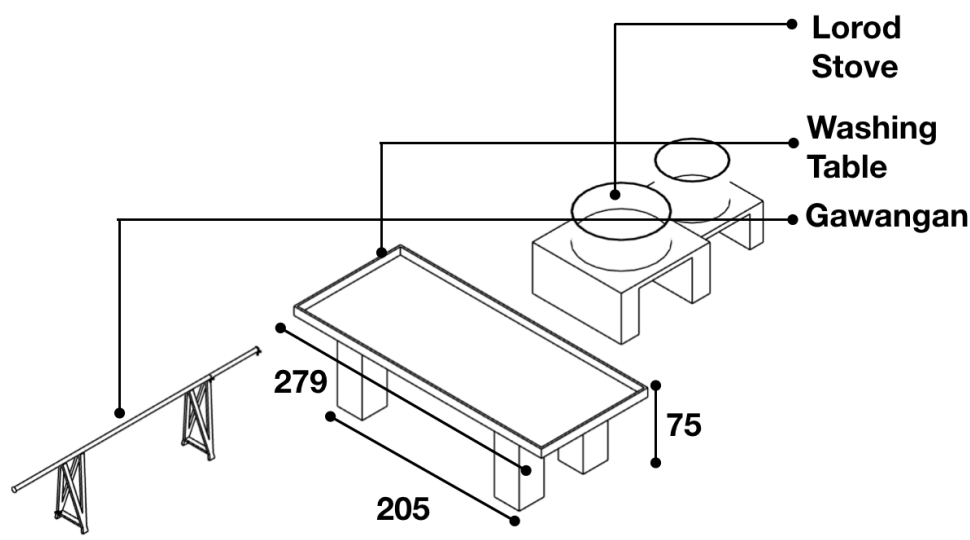

Figure 7. The washing table dimension in centimeter

\subsection{The Dyeing Process}

The traditional dyeing tool is immovable according to their space requirements. The modified dyeing tool has a more massive design, so the position does not change. Traditional dyeing tools made of wood. The initial design has been maintained by the original since the first generation of Oey Soe Tjoen. The dyeing process using this dyeing tool is maintained by the business owner as well as the dyeing worker, Widianti Widjaja because she wants to maintain the tradition in the coloring process that has been going on for generations since the first generation of Oey Soe Tjoen. The dyeing process that must be carried out by two people is believed to be more effective in giving color to the fabric because the process is more thorough and is assisted by bamboo stems in the middle of the tool.

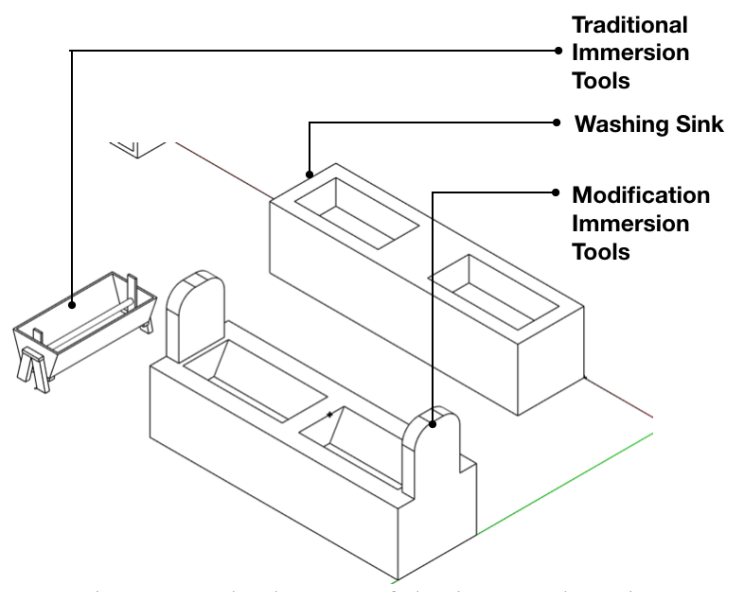

Figure 8. The layout of dyeing workstation

The process of coloring batik Peranakan Oey Soe Tjoen ultimately uses the dye technique. The series of coloring processes producing a specific color through the dyeing process of fabric into the water, which has artificial coloring materials under a specific dose. The coloring process takes place repeatedly until the color 
permeates into the fabric following the desired color. This time-consuming process turns the dyeing tool into a very influential tool in the coloring process. The traditional dyeing tool has a low working platform, almost directly in contact with the ground. The low height of the platform causes the movement of workers up and down to form a curve of about one hundred eighty degrees, repetitively by supporting the weight of the wet fabric. This movement then causes discomfort to the worker's body, especially the lower back.
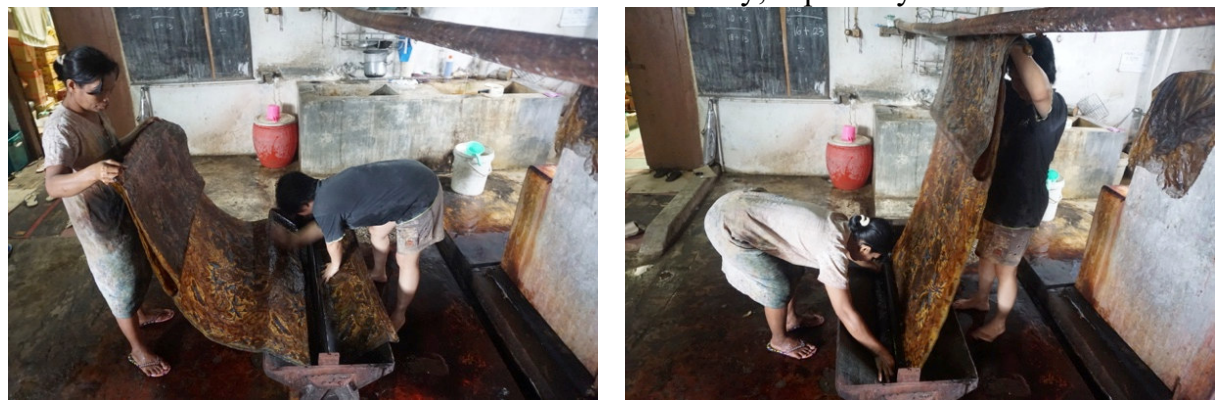

Figure 9. The dyeing process using traditional dyeing tool

Based on these considerations, Widianti as the business owner and also the dyeing worker decided to modify the dyeing tools to make them more comfortable for the worker's bodies. After getting a reference from a batik workshop located in Yogyakarta, Widianti made a dyeing tool according to her needs based on the size of the fabric, the number of workers, the dyeing procedure, and the coloring workstation. Modified dyeing tools with higher work platforms function to carry out the dyeing process independently, thus requiring two units of this tool for time effectiveness. Through this new design makes the lower back of the worker's body more comfortable. Raising the work platform higher than the traditional dyeing tool causes the body to move a shorter curve, around ninety degrees. However, due to the large and massive dimension of the modification dyeing tools, these units are not flexible for the coloring workstation.
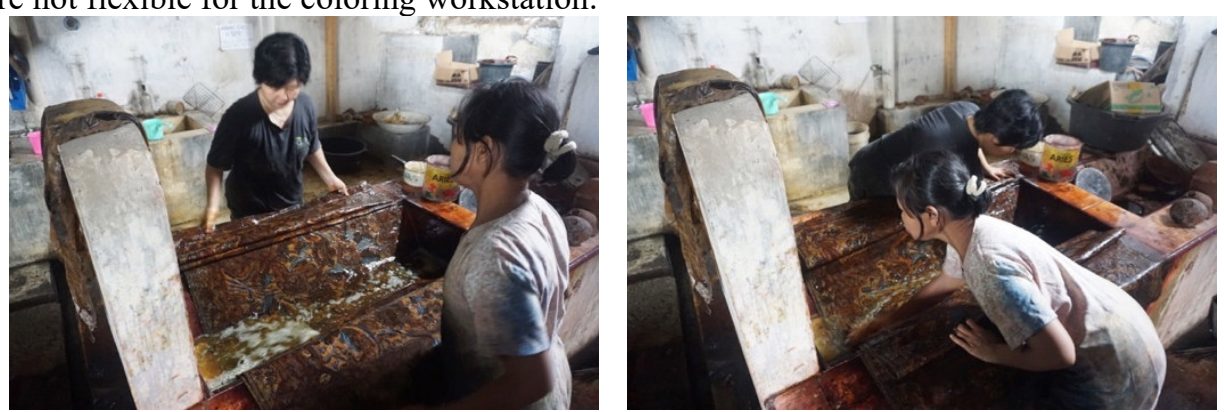

Figure 10. The dyeing process using modified dyeing tool
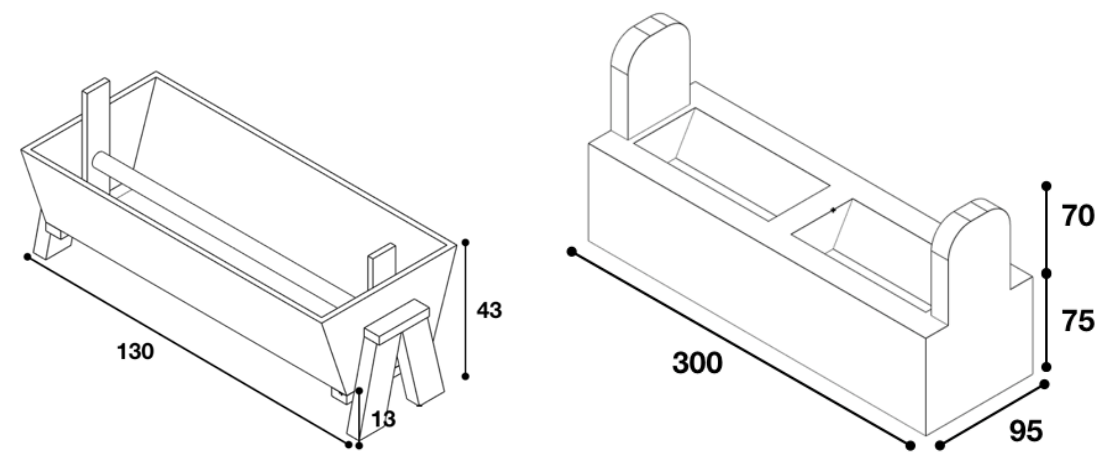

Figure 11. The dimension of traditional and modified dyeing tool in centimeter

Because of the higher working platform, the ability to pull up the fabric by workers is limited. Therefore, the fabric is more often placed on the surface of the tool and then soaked in the colored water. The dimensions of the tool are quite large, using more space. The massive shape makes this modification dying tool, less flexible, so it affects the circulation in the coloring workstation. As the research progresses, several considerations taken by Widianti Widjaja as workers as well as the owner of the batik business. Changes made to the dyeing tool have an impact on the layout of the tool and the layout of the coloring workstation in this batik workshop. Traditional dyeing is moveable and quickly make adjustments to space and users. However, the modification dyeing tool applies in reverse. Nevertheless, with some adjustments in the process, Widianti only needs one unit of the modification dyeing tool. The changes make both tools that can be adjacent to others to facilitate circulation and production flow, so increases the effectiveness of the space that supports work productivity in the dyeing process. 


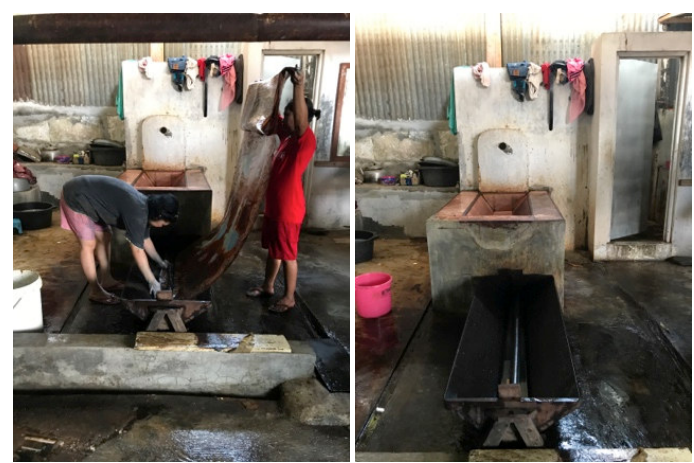

Figure 12. The changes in layout of the dyeing workstation

\section{Conclusion}

The Oey Soe Tjoen batik workshop, which has existed for almost a hundred years and is managed by three generations, has undoubtedly experienced several changes, both in the evolution of the pattern and the process of making batik. Although the process of making batik is still maintained following the first generation traditionally, some adjustments were seen, especially in the equipment used. The adjustment is because there are differences in habits of working, the development of science, and awareness of effective working processes. The following is a summary of tool changes that occurred in the correction process, washing process, and coloring process:

Table 1. Increase the working platform height in three batik processes

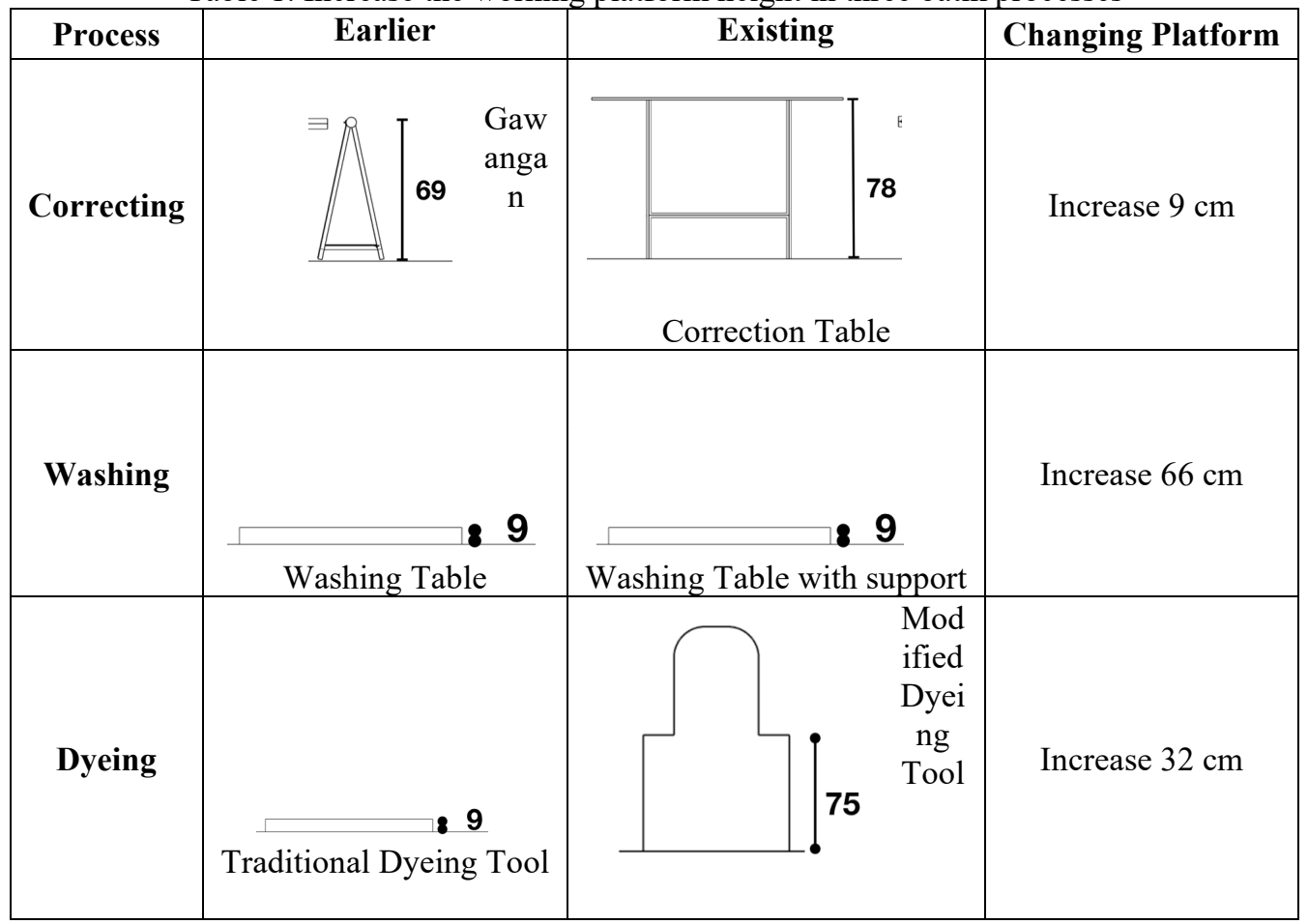

From the table above, it appears that the highest increase of $66 \mathrm{~cm}$ occurred in the washing table tool. At first, the washing process done at the washing table located on the floor with $9 \mathrm{~cm}$ height. In the correction process, there is a difference that not only changes the tool's height to $78 \mathrm{~cm}$ but also its slope. The height is adjusted to the user and her working habits on the correction process, namely Widianti Widjaja. Especially for the coloring process, two dying tools, both traditional and modified dyeing tools, are still used today.

The increase in working platforms and changes in equipment used at the Oey Soe Tjoen batik workshop are based on consideration of postural comfort. The body posture of the worker and owner of a batik business that is different in each generation causes modifications to some of the equipment used. The body posture of the worker and owner of the batik business is different in each generation, causing modifications to some of the equipment used. Postural condition of Muljadi Widjaja as the second generation and the working habits of Widianti Widjaja as the third generation of Oey Soe Tjoen in doing detailed work in a high working platform, causing an increase in work platforms as high as approximately seventy-five to eighty centimeters from the floor surface. Changes in the number of dyeing tools also support comfort in space circulation and production flow, thereby increasing productivity in the process of dyeing fabrics. 
The process of making Peranakan batik which has been going on for generations since the first generation of Oey Soe Tjoen has been maintained until now, this includes the use of traditional dyeing tool, which aim to preserve traditions that were passed down from their ancestors, directly only to the descendants of the Oey family. By keeping this tradition, the traditional values contained in each process of making batik is still maintained. The use of traditional dyeing tools that must be carried out by these two dyeing workers also still maintains the value of cooperation in producing batik. Two people who work as well as establish communication to coordinate may later strengthen the bonds of fellow workers, which increases harmony in the work system. Therefore, it can be said that the Peranakan Oey Soe Tjoen batik workshop uses technology and still maintains the tradition.

\section{References}

Bridger, R.S. (1995). Introduction to ergonomics. McGraw-Hill, Inc.

Dharsono (2019). The Dynamics of Surakarta Batik: The Development of Batik Through Conservation by Revitilization and Reinterpretation in The Development Dynamics of Surakarta Batik, Art and Design Studies, 74

Komunitas Lintas Budaya Indonesia dan Intisari (2018). Peranakan Tionghoa Indonesia: Sebuah perjalanan budaya, Intisari - Kompas Gramedia

Kroemer, KHE \& Grandjean, E. (2009). Fitting the Task to the Human: A Textbook of Occupational Ergonomics Fifth Edition, Taylor \& Francis e-Library

Kudiya, K. (2019). Kreativitas dalam desain batik. ITB Press

Liong, W. (2014). Oey Soe Tjoen: Duta batik Peranakan. Kementrian Pariwisata Republik Indonesia dan Red \& White Publishing. 